\title{
Distribution of trace elements in tissues of shrimp species Litopenaeus vannamei (Boone, 1931) from Bahia, Brazil
}

\author{
E. Silva ${ }^{a *}$, Z. C. V. Viana ${ }^{b}$, C. R. E. Onofre ${ }^{c}$, M. G. A. Korn ${ }^{c}$ and V. L. C. S. Santos \\ ${ }^{a}$ Unidade Acadêmica de Ciências Biológicas, Universidade Federal de Campina Grande - UFCG, \\ Av. Universitária, s/n, CP 61, CEP 58708-110, Patos, PB, Brazil \\ 'Instituto de Ciências da Saúde, Universidade Federal da Bahia - UFBA, Av. Reitor Miguel Calmon, s/n, \\ Vale do Canela, CEP 40110-100, Salvador, BA, Brazil \\ 'Instituto de Química, Universidade Federal da Bahia - UFBA, Rua Barão de Jeremoabo, s/n, \\ Ondina, CEP 40170-115, Salvador, BA, Brazil \\ *e-mail: edevaldo@cstr.ufcg.edu.br
}

Received: August 19, 2014 - Accepted: November 24, 2014 - Distributed: February 29, 2016

(With 2 figures)

\begin{abstract}
In this study, concentrations of trace elements in tissues of shrimp species (Litopenaeus vannamei) from farming and zone natural coastal located in the northeastern Brazil were investigated. The elements determination was performed by optical emission spectrometry with inductively coupled plasma (ICP OES). The following ranges of concentrations in the tissues were obtained in $\mu \mathrm{g} \mathrm{g}^{-1}$ dry weight: Al: 13.4-886.5, Cd: 0.93-1.80; Cu: 24.8-152; Fe: 3.2-410.9; Mn: 0.36-24.4; Se: 0.094-9.81 and Zn: 20.3-109.4. The shrimp muscle can be a good iron source (about $88.9 \mathrm{mg}^{-1} \mathrm{~g} \mathrm{dry}$ weight). The distribution of Se concentration in tissues showed much variation between locations, and the concentration levels found in shrimp muscles of wild samples were high, where its levels in $67 \%$ of muscle and $50 \%$ of others tissues samples exceeded the ANVISA limit, indicating evidence of selenium bioaccumulation. Significant correlation was observed between the following pairs of elements: $\mathrm{Fe}-\mathrm{Zn}(\mathrm{r}=-0.70), \mathrm{Mn}-\mathrm{Cu}(\mathrm{r}=-0.74), \mathrm{Se}-\mathrm{Cu}(\mathrm{r}=-0.68), \mathrm{Se}-\mathrm{Mn}$ $(\mathrm{r}=0.82)$ in the muscles; Fe-Al $(\mathrm{r}=0.99), \mathrm{Mn}-\mathrm{Al}(\mathrm{r}=0.62), \mathrm{Mn}-\mathrm{Fe}(\mathrm{r}=0.62), \mathrm{Se}-\mathrm{Al}(\mathrm{r}=0.88), \mathrm{Se}-\mathrm{Fe}(\mathrm{r}=0.87), \mathrm{Se}-\mathrm{Mn}$ $(\mathrm{r}=0.58)$ in the exoskeleton and $\mathrm{Cu}-\mathrm{Zn}(\mathrm{r}=0.68), \mathrm{Al}-\mathrm{Cu}(\mathrm{r}=0.88), \mathrm{Fe}-\mathrm{Cu}(\mathrm{r}=0.95)$ and $\mathrm{Fe}-\mathrm{Al}(\mathrm{r}=0.97)$ in the viscera.
\end{abstract}

Keywords: Todos os Santos Bay, shrimp, trace elements, bioaccumulation, ICP OES.

\section{Distribuição de elementos traço em tecidos do camarão Litopenaeus vannamei (Boone, 1931) da Bahia, Brasil}

\section{Resumo}

Esse estudo teve como objetivo avaliar as concentrações de elementos traço em tecidos da espécie de camarão Litopenaeus vannamei coletadas da zona costeira e de carciniculturas localizadas no nordeste do Brasil. Os elementos químicos foram determinados por espectrômetro de emissão óptica com plasma indutivamente acoplado (ICP OES). Foram encontradas as seguintes faixas de concentrações desses elementos nos tecidos (em mg g-1 peso seco): Al: 13,4-886,5; Cd: 0,93-1,80; Cu: 24,8-152; Fe: 3,2-4109; Mn: 0,36-24,4; Se: 0,094-9,81 and Zn: 20,3-109,4. O músculo do camarão investigado pode ser uma boa fonte de ferro (cerca de $88.9 \mathrm{mg}-1 \mathrm{~g}$ peso seco). A distribuição da concentração de Se nos tecidos apresentou muita variação entre as localidades, com níveis acima do estabelecido pela ANVISA para 67\% dos musculos e 50\% dos outros tecidos investigados, indicando evidências de bioacumulação do selênio. Houve correlações significativas entre os seguintes pares de elementos:: Fe- $\mathrm{Zn}(\mathrm{r}=-0,70), \mathrm{Mn}-\mathrm{Cu}(\mathrm{r}=-0,74), \mathrm{Se}-\mathrm{Cu}(\mathrm{r}=-0,68), \mathrm{Se}-\mathrm{Mn}$ $(\mathrm{r}=0,82)$ nos músculos, Fe-Al ( $\mathrm{r}=0,99), \mathrm{Mn}-\mathrm{Al}$ e $\mathrm{Mn}-\mathrm{Fe}(\mathrm{r}=0,62)$, Se-Al $(\mathrm{r}=0,88), \mathrm{Se}-\mathrm{Fe}(\mathrm{r}=0,87), \mathrm{Se}-\mathrm{Mn}(\mathrm{r}=0,58)$ no exoesqueleto e $\mathrm{Cu}-\mathrm{Zn}(\mathrm{r}=0,68), \mathrm{Al}-\mathrm{Cu}(\mathrm{r}=0,88), \mathrm{Fe}-\mathrm{Cu}(\mathrm{r}=0,95)$ and $\mathrm{Fe}-\mathrm{Al}(\mathrm{r}=0,97)$ nas vísceras.

Palavras-chave: Baia de Todos os Santos, camarão, elementos traço, bioacumulação, ICP OES.

\section{Introduction}

Intensive shrimp aquaculture is a recent development of the Brazilian agribusiness but has increased by about $20 \%$ per year during the last decade, particularly along the semi-arid northeastern coast of Brazil due to the optimal climate and environmental setting (Gräslund and Bengtson, 2001).

Seafood products are indicated as part of a balanced human diet. Nevertheless, many species of marine 
invertebrates are known to accumulate trace elements in its tissues and can be a potential source of inorganic contaminants (Fallah et al., 2011).

Shrimp farms generally are located next to the coast and use the seawater directly from the coastal area to farm shrimps (Wu and Chen, 2004). Coastal zones located near major urban areas are often subjected to severe contamination (Diodato et al., 2012), such as trace elements, which are often problematic environmental pollutants.

Trace elements are natural hydrosphere constituents. However, anthropogenic activities have altered the geochemical cycle, increasing environmental concern regarding these pollutants (Ferreira et al., 2005).

Its accumulation in the aquatic environment may favor a probable bioaccumulation and biomagnification in organisms along the food chain of the aquatic ecosystem (Dural et al., 2007), magnifying its toxic power in consumers in the chain top as whales, birds and man (Fu et al., 2011). Biomonitoring of trace elements is essential to assess ecosystem health (Duran et al., 2007; Yetimoglu et al., 2007). Metals can be categorized as: potentially toxic (Al-aluminium, As-arsenic, Cd-cadmium, Sb-antimony, $\mathrm{Pb}$-lead, Hg-mercury) probably essential like Ni-nickel $\mathrm{V}$-vanadium, Co-cobalt and essential like $\mathrm{Cu}$-copper, Zn-zinc, Se-selenium etc. (Tuzen and Soylak, 2007). The essential metals can also be toxic when excessively elevated intake is of concern.
For these reasons, the monitoring of trace elements in intensive shrimp farms is essential. The purpose of this work was to characterize the levels of aluminum ( $\mathrm{Al}$ ), cadmium $(\mathrm{Cd})$, copper $(\mathrm{Cu})$, iron $(\mathrm{Fe})$, lead $(\mathrm{Pb})$, molybdenum $(\mathrm{Mo})$, manganese $(\mathrm{Mn})$, selenium $(\mathrm{Se})$ and zinc $(\mathrm{Zn})$ in some tissues of the major economically important shrimp specie Litopenaeus vannamei caught off farms and zone natural coastal located in the Bahia, Brazil.

\section{Material and Methods}

\subsection{Sampling}

Todos os Santos Bay is a tropical largest Bay, with approximately $1,000 \mathrm{Km}^{2}$, located in the state of Bahia (Brazil). This Bay receives environmental impacts arising from activities in the metropolitan area of Salvador, and industrial sources including: chemical and petrochemical plants, as well as an oil refinery and harbor activities located in the North and Northeastern area of the bay (Amado-Filho et al., 2008).

Shrimp samples (Litopenaeus vannamei) were collected directly from the four sites: three shrimp farms (Guaibim - GUA, Salina das Margaridas - SAL I and SAL II, Santo Amaro - SAM) and a sampling site of wild shrimp caught in the natural coastal zone (Mar Grande - MAG II and I) of Todos os Santos Bay (Figure 1).

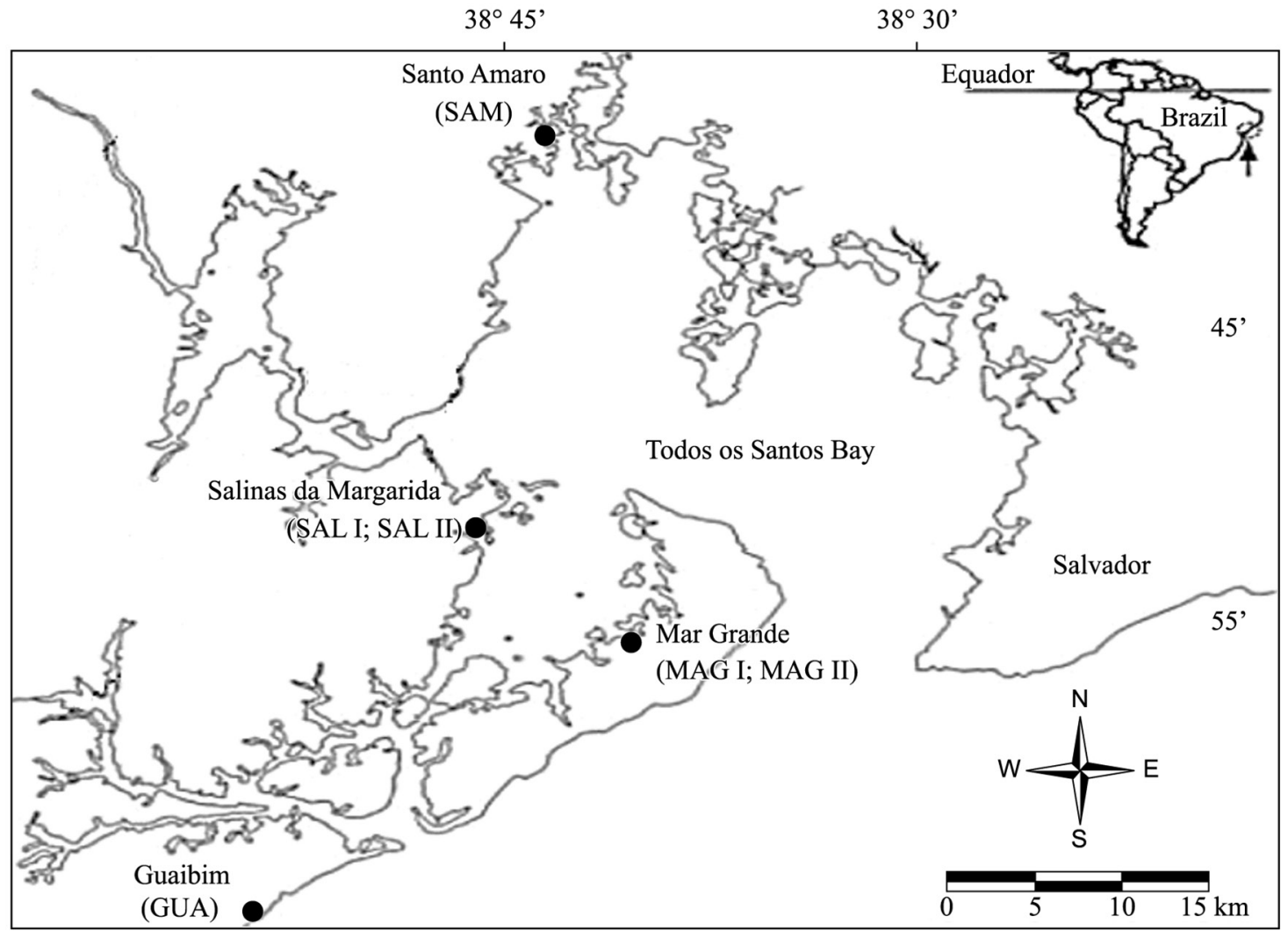

Figure 1. Location of the four collection sites studied (Salinas da Margarida, Guaibim, Santo Amaro and Mar Grande) at Todos os Santos Bay, state of Bahia (BA), Brazil. 
They were collected and composite sub-samples of muscle tissue, exoskeleton and viscera from 76 to 120 individuals were used for analysis. Samples were stored individually in sterile polyethylene vials at $-20^{\circ} \mathrm{C}$, freeze-dried and homogenized (particles $<149 \mathrm{mM}, 100$ mesh aperture). The humidity percentage in the muscle tissue was $78 \pm 2 \%$.

\subsection{Sample preparation}

The farmed shrimps were collected using a non-metallic net, and the wild shrimp were bought from local fishermen. After collection, biometric measurements (body length and body weigh) were performed in shrimps of each site. Each white shrimp weighed 19.2-25.9 g, all market size (Table 1). Shrimps were transferred to labelled, zip-lock bags and stored in cool box for referral to the laboratory, where the exoskeleton, muscle and viscera were separated, respectively.

To minimize contamination, all the materials used in the experiments were previously washed in ultra-pure water, and a stainless steel knife was used to cut the tissues. Masses of $200 \mathrm{mg}$ of samples were directly introduced into PTFE closed vessels with volumes of $23 \mathrm{~mL}$. A volume of $2.0 \mathrm{~mL}$ of ultrapure nitric acid solutions was added to each vessel. Then, a volume of $2.0 \mathrm{~mL}$ of $\mathrm{H}_{2} \mathrm{O}$ was also added to each reaction vessel. Parr bombs were sealed and put in a heating oven set at $110 \pm 10^{\circ} \mathrm{C}$ and remained at this temperature during $12 \mathrm{~h}$. After cooling down at room temperature, solutions were transferred to glass volumetric flasks and volumes were made up to $10.0 \mathrm{~mL}$ with ultrapure water (Milli-Q ${ }^{\circledR}$, Millipore, USA).

\subsection{Apparatus}

An inductively coupled plasma optical emission spectrometer (ICP OES) with axially viewed configuration (VISTA PRO, Varian, Mulgrave, Australia) equipped with a solid state detector, a cyclonic spray chamber, and a concentric nebulizer was employed for trace elements determinations. The ICP OES condition used for this study was as follows: RF power: $1.3 \mathrm{~kW}$; gas: argon; plasma flow: $15 \mathrm{l} / \mathrm{min}$; auxiliary flow: $1.5 \mathrm{l} / \mathrm{min}$; nebulizer flow: $0.75 \mathrm{l} / \mathrm{min}$; instrument stabilization delay: $15 \mathrm{~s}$; pump rate: $15 \mathrm{rpm}$; sample uptake delay: $70 \mathrm{~s}$; number of replicates: 3; read time: $5 \mathrm{~s}$; read: peak height; rinse time: $30 \mathrm{~s}$.

The precision and accuracy of the method employed for the determinations were validated by analysis in triplicate of certified reference materials (CRM), from National Research Council Canada (BCR-422, cod muscle) and a standards reference materials (SRM) from National Bureau of Standards Certificate of Analysis, NIST (SRM-1566b, oyster tissue), using the same analytical procedure. The results indicated good agreement between the certified and analytical values (Table 2). The recovery rates were found between $89 \%$ and $104 \%$ ( $\mu \mathrm{g} \mathrm{g}^{-1} / \mathrm{dry}$ weight).
Analytical blanks were run in the same way as the samples and the concentrations were determined using the standard solutions prepared in the same acid matrix.

\subsection{Reagents and solutions}

All reagents were of analytical grade unless otherwise stated. Ultrapure water (Milli-Q ${ }^{\circledR}$, Millipore, USA) with conductivity lower than $18.2 \mathrm{~m} \Omega \mathrm{cm}^{-1}$ was used throughout. The multielement reference solutions were prepared daily from $1000 \mathrm{mg} \mathrm{L}^{-1}$ stock solutions of each element (Titrisol ${ }^{\circledR}$, Merck, Germany). Laboratory glassware was kept overnight in $10 \%(\mathrm{v} / \mathrm{v})$ nitric acid solution. Before use, the glassware was rinsed with deionized water and dried in a dust free environment.

\subsection{Statistical analysis}

Each reported result was the average value of the three analyses. The results were offered as means \pm SEM. Kruskal-Wallis H test, which was followed by Mann-Whitney $\mathrm{U}$ test to comparisons of particular pairs of samples by locations and by tissues. For correlation analysis between the values in tissues was used the Spearman correlation coefficients and linear regression (Mingoti, 2007). Results were considered significant at $\mathrm{p}<0.05$.

Table 1. Biometry of $L$. vannamei used for trace-element analysis $(n=70$; mean \pm SD).

\begin{tabular}{ccc}
\hline Sites & $\begin{array}{c}\text { Average body } \\
\text { length } \mathbf{( c m})\end{array}$ & $\begin{array}{c}\text { Average body } \\
\text { weight }(\mathbf{g})\end{array}$ \\
\hline SAL I & $12.5 \pm 0.6$ & $24.0 \pm 0.4$ \\
SAL II & $12.7 \pm 0.5$ & $24.3 \pm 0.6$ \\
GUA & $11.7 \pm 0.5$ & $23.6 \pm 0.5$ \\
SAM & $11.3 \pm 0.4$ & $23.4 \pm 0.8$ \\
MAG I & $8.2 \pm 0.3$ & $19.2 \pm 0.5$ \\
MAG II & $15.6 \pm 0.8$ & $25.9 \pm 0.4$ \\
\hline
\end{tabular}

Table 2. Measured and certified values of trace elements concentrations $\left(\mu \mathrm{g} \mathrm{g}{ }^{-1} \mathrm{dw}\right)$ in standard reference material BCR-422 (cod muscle) and SRM-1566b (oyster tissue).

\begin{tabular}{cccc}
\hline $\begin{array}{c}\text { Reference } \\
\text { material }\end{array}$ & $\begin{array}{c}\text { Certified } \\
\text { values }\end{array}$ & $\begin{array}{c}\text { Measured } \\
\text { values }\end{array}$ & $\begin{array}{c}\text { Recovery } \\
(\%)\end{array}$ \\
\hline BCR-422 & & & \\
$\mathrm{Mn}$ & $0.543 \pm 0.028$ & $0.494 \pm 0.031$ & 91 \\
$\mathrm{Fe}$ & $5.46 \pm 0.30$ & $4.91 \pm 0.29$ & 90 \\
$\mathrm{Cu}$ & $1.05 \pm 0.07$ & $0.93 \pm 0.06$ & 89 \\
$\mathrm{Se}$ & $1.63 \pm 0.07$ & $1.59 \pm 0.04$ & 98 \\
$\mathrm{~Pb}$ & $0.085 \pm 0.015$ & $0.079 \pm 0.023$ & 93 \\
$\mathrm{Zn}$ & $19.6 \pm 0.5$ & $18.79 \pm 0.32$ & 96 \\
$\mathrm{SRM-1566b}$ & & & \\
$\mathrm{Cd}$ & $2.48 \pm 0.08$ & $2.29 \pm 0.13$ & 92 \\
$\mathrm{Cu}$ & $71.6 \pm 1.6$ & $64.55 \pm 2.21$ & 90 \\
$\mathrm{Fe}$ & $205.8 \pm 6.8$ & $210.61 \pm 2.7$ & 102 \\
$\mathrm{Mn}$ & $18.5 \pm 0.2$ & $16.42 \pm 0.05$ & 89 \\
$\mathrm{Se}$ & $2.06 \pm 0.15$ & $2.15 \pm 0.14$ & 104 \\
\hline
\end{tabular}




\section{Results and Discussion}

\subsection{Distribution of trace elements in tissues}

Average total body length and average body weight of the L. vannamei for each site are shown in Table 1. Trace elements results obtained for each sites and different tissues are summarized in Table 3. These results indicate that trace elements accumulation is greater in viscera than in muscle in shrimp from all areas, except for Zn. However, different trends of bioaccumulation were observed between analyzed tissues.

For instance, ascending order of trace elements accumulation in muscles of $L$. vannamei was $\mathrm{Al}>\mathrm{Cu}>$ $\mathrm{Fe}>\mathrm{Zn}>\mathrm{Se}>\mathrm{Mn}>\mathrm{Pb}, \mathrm{Mo}$. The concentrations of lead and molybdenum were all below the LOQ. For all other elements investigated there was a greater tendency to accumulate in the visceral tissue. The decreasing order of accumulation was $\mathrm{Zn}, \mathrm{Cu}, \mathrm{Fe}, \mathrm{Al}$ and $\mathrm{Mn}$; it became clear to most samples: viscera $>$ exoskeleton $>$ muscles. Regarding the Se, this order was not well defined, showing a great variability of accumulation between tissues.

Zinc was detected in all examined shrimp samples and its concentrations ranged from: $36.6-43.8 \mu \mathrm{g} \mathrm{g}^{-1}$ in muscle, $16.8-109.4 \mu \mathrm{g} \mathrm{g}^{-1}$ in viscera, $38.0-53.7 \mu \mathrm{g} \mathrm{g}^{-1}$ in exoskeleton. The presence of zinc in higher concentration in the viscera of shrimps of natural water is probably related to the increased bioavailability of this element in the aquatic environment and due to the enzymatic role as regulator of several enzymes of the hepatopancreas and glands on the animal's head (Bryan and Langston, 1992). Its enzymatic activity regulates the metabolism of nucleic acids, carbohydrates and proteins. Thus, its concentrations are high in all tissues compared to other trace elements.

This order of zinc concentration (viscera $>$ muscle $>$ exoskeleton) found in MAGII is similar to most reported studies on wild shrimp species (Darmono and Denton, 1990; Mendéz et al., 1999). When the shrimp is exposed to zinc excess in polluted environment, the concentration ratio of this element increases in its body.

Due to the high affinity for metallothionein, zinc has low excretion rate and tends to accumulate inside the cell in a non-toxic form reducing its purification (Amaral et al., 2005). Thus, its concentrations are high in all tissues compared to other trace elements.

The highest copper concentrations were found in visceral samples. Its concentrations ranged from: $24.8-33.9 \mu \mathrm{g} \mathrm{g}^{-1}$ in muscle, 81.9-152.0 $\mathrm{\mu g} \mathrm{g}^{-1}$ in viscera, 55.9-77.6 $\mu \mathrm{g} \mathrm{g}^{-1}$ in exoskeleton. Similar trend was also reported in shrimp samples of Paleomonetes varians (Leach, 1813), Dorippe granulate (De Haan, 1841) (Alliot and Frenet-Piron, 1990; Depledge et al., 1993; Páez-Osuna and Tron-Mayen, 1996) and L. vannamei collected in Jaguaribe River estuary, located in Ceará, Northeast Brazil, where reported similar concentration range 23.2 to $63.4 \mu \mathrm{g} \mathrm{g}^{-1} \mathrm{~d}$.w. (Lacerda et al., 2009).

Table 3. Elemental concentrations ( $\mu \mathrm{g} \mathrm{g}^{-1} \mathrm{dw}$ ) in shrimp (Litopenaeusvannamei) tissue samples from sites in Todosos Santos Bay, Salvador, Bahia.

\begin{tabular}{|c|c|c|c|c|c|c|c|}
\hline $\mathbf{E}$ & $\mathbf{T}$ & SAL I & SAL II & GUA & SAM & MAG I & MAG II \\
\hline \multirow{3}{*}{$\mathrm{Zn}$} & $\mathrm{M}$ & $42.1 \pm 0.4^{\mathrm{ab}}$ & $40.8 \pm 0.7^{b}$ & $42.3 \pm 0.2^{\mathrm{ab}}$ & $36.6 \pm 0.2^{\mathrm{c}}$ & $44.3 \pm 1.6^{\mathrm{a}}$ & $43.8 \pm 1.9^{\mathrm{ab}}$ \\
\hline & $\mathrm{V}$ & $34.2 \pm 0.2^{\mathrm{c}}$ & $28.0 \pm 0.7^{\mathrm{d}}$ & $16.8 \pm 1.5^{\mathrm{e}}$ & $20.3 \pm 0.3^{\mathrm{e}}$ & $91.6 \pm 1.3^{b}$ & $109.4 \pm 4.7^{\mathrm{a}}$ \\
\hline & $\mathrm{E}$ & $52.1 \pm 1.1^{\mathrm{a}}$ & $53.7 \pm 0.9^{a}$ & $53.0 \pm 1.5^{a}$ & $53.2 \pm 0.6^{a}$ & $51.0 \pm 5.8^{a}$ & $38.0 \pm 1.3^{b}$ \\
\hline \multirow{3}{*}{$\mathrm{Cu}$} & $\mathrm{M}$ & $28.3 \pm 0.4^{c}$ & $32.7 \pm 0.4^{b}$ & $33.9 \pm 0.1^{a}$ & $27.8 \pm 0.2^{c}$ & $23.1 \pm 0.3^{\mathrm{e}}$ & $24.8 \pm 0.5^{\mathrm{d}}$ \\
\hline & $\mathrm{V}$ & $82.6 \pm 1.1^{\mathrm{d}}$ & $117.7 \pm 1.2^{\mathrm{bc}}$ & $81.9 \pm 4.6^{d}$ & $103.7 \pm 1.2^{\mathrm{c}}$ & $152.0 \pm 0.4^{\mathrm{a}}$ & $132.6 \pm 12.5^{b}$ \\
\hline & $\mathrm{E}$ & $76.0 \pm 2.3^{\mathrm{ab}}$ & $77.6 \pm 1.1^{\mathrm{a}}$ & $55.9 \pm 3.0^{\mathrm{c}}$ & $70.2 \pm 0.6^{b}$ & $55.8 \pm 0.7^{\mathrm{c}}$ & $75.3 \pm 3.3^{\mathrm{ab}}$ \\
\hline \multirow{3}{*}{$\mathrm{Al}$} & $\mathrm{M}$ & ND & $117.8 \pm 2.9^{\mathrm{c}}$ & ND & $65.0 \pm 1.5^{c}$ & $121.7 \pm 6.2^{b}$ & $66.4 \pm 0.7^{c}$ \\
\hline & $\mathrm{V}$ & $60.7 \pm 1.5^{f}$ & $359.9 \pm 7.8^{c}$ & $217.2 \pm 5.7^{d}$ & $125.3 \pm 4.9^{\mathrm{e}}$ & $886.5 \pm 6.2^{\mathrm{a}}$ & $389.1 \pm 8.9^{b}$ \\
\hline & $\mathrm{E}$ & $13.4 \pm 0.5^{\mathrm{e}}$ & $138.0 \pm 3.5^{\mathrm{a}}$ & $23.2 \pm 6.5^{\mathrm{e}}$ & $70.0 \pm 0.5^{d}$ & $206.7 \pm 6.7^{\mathrm{a}}$ & $178.5 \pm 6.5^{b}$ \\
\hline \multirow{3}{*}{$\mathrm{Fe}$} & $\mathrm{M}$ & $5.0 \pm 0.6^{\mathrm{e}}$ & $86.0 \pm 0.2^{\mathrm{a}}$ & ND & $63.4 \pm 0.4^{b}$ & $60.3 \pm 0.6^{c}$ & $34.5 \pm 0.4^{d}$ \\
\hline & $\mathrm{V}$ & $41.3 \pm 1.2^{\mathrm{e}}$ & $117.7 \pm 1.2^{\mathrm{c}}$ & $63.5 \pm 3.4^{d}$ & $65.8 \pm 5.6^{d}$ & $410.9 \pm 0.8^{c}$ & $197.4 \pm 4.9^{b}$ \\
\hline & $\mathrm{E}$ & $3.2 \pm 0.1^{\mathrm{d}}$ & $96.9 \pm 2.6^{b}$ & $5.4 \pm 3.2^{\mathrm{d}}$ & $71.9 \pm 2.1^{\mathrm{c}}$ & $213.8 \pm 15.7^{\mathrm{a}}$ & $103.8 \pm 1.2^{b}$ \\
\hline \multirow{3}{*}{$\mathrm{Mn}$} & M & $0.82 \pm 0.04^{\mathrm{c}}$ & $0.36 \pm 0.02^{\mathrm{e}}$ & $0.86 \pm 0.04^{\mathrm{d}}$ & $2.1 \pm 0.1^{\mathrm{b}}$ & $3.17 \pm 0.11^{\mathrm{a}}$ & $1.20 \pm 0.04^{\mathrm{c}}$ \\
\hline & $\mathrm{V}$ & $1.36 \pm 0.18^{\mathrm{d}}$ & $0.97 \pm 0.09^{\mathrm{d}}$ & $1.48 \pm 0.08^{\mathrm{d}}$ & $9.81 \pm 0.27^{b}$ & $24.4 \pm 0.3^{a}$ & $9.12 \pm 0.38^{c}$ \\
\hline & $\mathrm{E}$ & $0.85 \pm 0.01^{\mathrm{d}}$ & $0.38 \pm 0.01^{\mathrm{c}}$ & $0.67 \pm 0.16^{\mathrm{c}}$ & ND & $20.7 \pm 0.1^{\mathrm{a}}$ & $16.98 \pm 0.32^{b}$ \\
\hline \multirow{3}{*}{$\mathrm{Cd}$} & M & $<$ LOQ & $<$ LOQ & $<$ LOQ & $<$ LOQ & $<$ LOQ & $<$ LOQ \\
\hline & $\mathrm{V}$ & $<$ LOQ & $<$ LOQ & $<$ LOQ & $<$ LOQ & $0.93 \pm 0.08^{\mathrm{a}}$ & $1.08 \pm 0.09^{b}$ \\
\hline & $E$ & $<\mathrm{LOQ}$ & $<\mathrm{LOQ}$ & $<\mathrm{LOQ}$ & $<\mathrm{LOQ}$ & $<\mathrm{LOQ}$ & $<\mathrm{LOQ}$ \\
\hline \multirow{3}{*}{$\mathrm{Se}$} & $\mathrm{M}$ & $0.82 \pm 0.06^{\mathrm{e}}$ & $1.09 \pm 0.05^{\mathrm{d}}$ & $1.47 \pm 0.38^{c}$ & $2.33 \pm 0.47^{b}$ & $3.97 \pm 0.02^{\mathrm{a}}$ & $3.68 \pm 0.41^{\mathrm{a}}$ \\
\hline & $\mathrm{V}$ & $<$ LOQ & $<$ LOQ & $<$ LOQ & $<$ LOQ & $9.72 \pm 0.34^{\mathrm{a}}$ & $9.81 \pm 0.34^{\mathrm{a}}$ \\
\hline & $\mathrm{E}$ & $0.16 \pm 0.02^{\mathrm{d}}$ & $3.97 \pm 0.03^{\mathrm{c}}$ & $0.08 \pm 0.01^{\mathrm{d}}$ & $3.84 \pm 0.06^{\mathrm{c}}$ & $5.45 \pm 0.5^{b}$ & $7.07 \pm 0.62^{\mathrm{a}}$ \\
\hline
\end{tabular}

Mean \pm S.D.(n=3); E: Elements. T: Tissues. Farms: SAL I e SAL II = Salina das Margaridas; GUA = Guaibim; SAM = Santo Amaro; Natural coastal zone, MAG I e MAG II= Mar Grande; $\mathrm{ND}=$ not detected; $\angle \mathrm{LOQ}=$ sample value below the limit of quantification $\left(\mathrm{Cd}=0.039 ; \mathrm{Se}=0.014 \mu \mathrm{g} \mathrm{g}^{-1}\right)$; Values of the same tissue sample, in the same line and letter, do not vary significantly. 
The gills, present in the visceral samples, are structures with essential function in crustacean's respiration. They can potentially accumulate trace elements by absorption through the gills or by consumption of contaminated sediments (Firat et al., 2008). The metal concentrations in the gills reflect the metal concentrations in water (Yilmaz, 2003). In the case of copper, its high concentration in the viscera, such as those found in samples of wild shrimps (MAG and MAG), may be due to adsorption of adhered material on the gills instead of passing to the metal metabolic pathway (Bambang et al., 1995). In addition, the high amount of this element found in the gills is related to the hemocyanin ability to connect to respiratory pigments present in high amounts in this organ (Páez-Osuna and Ruíz-Fernández, 1995a).

Aluminum concentration in the analyzed samples ranged from: $65.0-138.0 \mu \mathrm{g} \mathrm{g}^{-1}$ in muscle, $60.7-886.5 \mu \mathrm{g} \mathrm{g}^{-1}$ in viscera, $13.4-206.7 \mu \mathrm{g} \mathrm{g}^{-1}$ in exoskeleton. Iron contents in the tissues samples ranged from: $5.0-86.0 \mu \mathrm{g} \mathrm{g}^{-1}$ in muscle, 41.3-410.9 $\mu \mathrm{g} \mathrm{g}^{-1}$ in viscera, 3.2-213.8 $\mu \mathrm{g} \mathrm{g}^{-1}$ in exoskeleton.

For aluminum and iron, the higher concentrations found in the viscera can be directly related to the bioavailability of these metals in the environment for the shrimp. Aluminium and iron are distributed in all terrestrial compartments (Soni et al., 2001). The aluminum contamination in aquatic environments is mainly related to industrial effluents. The exoskeleton also can assimilate, by adsorption, some of this metal in the environment (Mansour and Sidky, 2002).

Few papers report research concerning to the Al concentration in crustaceans, being more frequent surveys on fish species. Mansour and Sidky (2002) also found high Al concentration ( $186 \mathrm{mg} \mathrm{g}^{-1}$ ) researching the shrimp species Penacus sp. from Lago Qarun in Egypt. They found that tissues of fish raised in crop farms had lower levels of $\mathrm{Fe}, \mathrm{Zn}, \mathrm{Mn}$ and $\mathrm{Cd}$ than fish in coastal waters. Similar behavior was observed in this study between samples of animals from natural water and shrimp farming samples.

This trend of order of iron accumulation among shrimp tissues was also observed by other authors investigating the same shrimp species (Páez-Osuna and Tron-Mayen, 1996). They also showed differences among the iron accumulation in the exoskeleton, where shrimps from farms showed lower concentrations than those found in wild animals. Also in this study, samples of wild shrimp exoskeleton had much higher concentrations than those found in the samples of shrimps from farms, such as Salinas da Margarida (SAL I e II).

Mn concentrations ranged from: $0.36-3.17 \mu \mathrm{g} \mathrm{g}^{-1}$ in muscle, $0.97-24.4 \mu \mathrm{g} \mathrm{g}^{-1}$ in viscera, $0.38-20.7 \mu \mathrm{g} \mathrm{g}^{-1}$ in exoskeleton. There is no literature data on the binding of $\mathrm{Mn}$ to metallothionein, but this element is probably linked to other specific cellular components that favor their bioaccumulation in the viscera (Podrug and Raspor, 2009).

The concentrations of lead and molybdenum were below the limit of quantification in all tissues analyzed $\left(0.010 \mu \mathrm{g} \mathrm{g}^{-1}\right.$ and $0.11 \mu \mathrm{g} \mathrm{g}^{-1}$, respectively), showing no accumulation of these chemicals by L. vannamei shrimp in cultivation environments

For cadmium, values were below the limit of quantification $\left(\mathrm{LOQ}=0.04 \mu \mathrm{g} \mathrm{g}^{-1}\right)$ for almost all samples except for those of viscera of wild shrimps.

The detectable concentrations of cadmium in the viscera of two samples of wild shrimps showed significant variation between them. This variation is likely due to the significant difference in body size among shrimps of both samples (MAG I and II), shown in biometrics.

Some studies have reported on the influence of body size on metal accumulation (Martin, 1974; Darmono and Denton, 1990; Ruelas-Inzunza and Páez-Osuna, 2004) where cadmium seems to behave inversely to manganese in relation to their concentration in tissues and body size of the organism investigated, which increases its concentration with increasing body size, whereas the manganese tends to accumulate at higher concentrations in smaller organisms.

Cadmium concentrations found in the viscera are below those observed in gills and hepatopancreas of different shrimp species surveyed in other regions (Páez-Osuna and Ruíz-Fernández, 1995b; Páez-Osuna and Tron-Mayen, 1996; Pourang and Amini, 2001; Kargin et al., 2001; Pourang et al., 2004).

Several studies have reported the concentration and toxicity of cadmium in shrimps (Páez-Osuna and Ruíz-Fernández, 1995b; Páez-Osuna and Tron-Mayen, 1996; Vanegas et al., 1997; Soegianto et al., 1999; Pourang and Amini, 2001; Kargin et al., 2001; Pourang et al., 2004; Wu and Chen, 2004; Seebaugh et al., 2005; Santos et al., 2013). The Cd concentrations in the shrimp body depend mainly on their levels in the environment since this element is not essential in the biochemical and physiological processes of this animal (Ruelas-Inzunza and Páez-Osuna, 2004).

The Se levels were found in the range of 0.82-3.97 $\mu \mathrm{g} \mathrm{g}^{-1}$ in muscle, $<0.014-9.81 \mu \mathrm{g} \mathrm{g}^{-1}$ in viscera, $0.08-7.07 \mu \mathrm{g} \mathrm{g}^{-1}$ in exoskeleton. The distribution of Se concentration in tissues showed variation between locations. In the wild shrimp (MAG and MAG), the descending order of concentration in tissues was: viscera $>$ exoskeleton $>$ muscle. While this sequence of distribution in tissues of shrimps collected in other sites presented the order: exoskeleton $>$ muscle $>$ viscera.

Viscera of wild shrimps had higher Se concentrations, which probably reflect the greater bioavailability of this metal in their aquatic environment. The selenium concentrations found in the muscles of shrimps analyzed are similar to the values obtained in other studies conducted with shellfish and benthic species with similar life habits elsewhere in the world (May et al., 2001; Peterson et al., 2002; Harding et al., 2005).

Selenium is the very narrow margin between beneficial nutritionally and potentially toxic levels to vertebrate animals. It is less toxic to most plants and invertebrates in comparison to vertebrates, particularly birds and fish (White et al., 2012).

Lemly (1995) proposed a protocol of selenium accumulation profile in the food chain to evaluate the 
toxicity of its concentration in fish and aquatic birds. According to their classification, selenium levels found in the muscles of the samples investigated show low risk of toxicity for shrimp farm samples and moderate risk for samples of wild shrimps. Thus, according to the protocol proposed, wild shrimp samples analyzed showed evidence of selenium bioaccumulation in the food chain and can cause adverse effects on populations of fish and birds. For human consumption, the values found for selenium concentration in all shrimps are higher than the tolerance limit $\left(0.30 \mu \mathrm{g} \mathrm{g}^{-1} \mathrm{w} / \mathrm{w}\right)$ set by ANVISA (1965).

Table 4. Rank order of concentrations of elements in tissues of L. vannamei.

\begin{tabular}{ll}
\hline \multicolumn{1}{c}{ Tissue } & \multicolumn{1}{c}{ Order } \\
\hline Muscle & $\mathrm{Al}>\mathrm{Cu}>\mathrm{Fe}>\mathrm{Zn}>\mathrm{Se}>\mathrm{Mn}>\mathrm{Pb}, \mathrm{Mo}$ \\
Exoskeleton & $\mathrm{Al}>\mathrm{Fe}>\mathrm{Cu}>\mathrm{Zn}>\mathrm{Mn}>\mathrm{Se}>\mathrm{Pb}, \mathrm{Mo}$ \\
Víscera & $\mathrm{Al}>\mathrm{Fe}>\mathrm{Cu}>\mathrm{Zn}>\mathrm{Mn}>\mathrm{Se}>\mathrm{Pb}, \mathrm{Mo}$ \\
& $\mathrm{Al}>\mathrm{Fe}>\mathrm{Zn}>\mathrm{Cu}>\mathrm{Mn}>\mathrm{Se}>\mathrm{Pb}, \mathrm{Mo}$ \\
& (MAGI e II) \\
\hline
\end{tabular}

Overall, metal concentrations in tissues studied varied in descending order (Table 4).

The order of concentration found to the muscle, exoskeleton and viscera of $L$. vannamei was similar to those previously reported to other species and $L$. vanname $i$ (Table 5). Overall, zinc, iron and copper have been prevalent in the muscles in previous studies (Table 5), different from the present study, whose the order of concentration found in these tissues for these elements was $\mathrm{Cu}, \mathrm{Fe}$ and $\mathrm{Zn}$ (Table 4) . However, in the exoskeleton and viscera they were similar to the results (Páez-Osuna and Tron-Mayen, 1996) found for the same species, for Metapenaeus affins (H. Milne-Edwards, 1837) and Penaeus merguiensis (De Man, 1888) (Pourang and Amini, 2001) and other similar studies (Table 5).

\subsection{Correlation among elements}

Correlation analysis and linear regression between pairs of trace elements showed a correlation level variation between different tissues $(\mathrm{p}<0.05)$, mainly involving pairs of

Table 5. Published rank orders of concentrations of elements in tissues of various species of shrimp.

\begin{tabular}{|c|c|c|c|}
\hline Species & Tissue & Order & Reference \\
\hline $\begin{array}{l}\text { Penaeusmonodon } \\
\text { (Fabricius, 1798) }\end{array}$ & Exoskeleton & $\begin{array}{l}\mathrm{Sr}>\mathrm{Mn}>\mathrm{Cu}>\mathrm{Zn}>\mathrm{As}>\mathrm{Mo}>\mathrm{Cr} \\
>\mathrm{Se}>\mathrm{Pb}>\mathrm{Cd}\end{array}$ & Tu et al. (2008) \\
\hline Metapenaeusaffins & Exoskeleton & $\mathrm{Fe}>\mathrm{Zn}>\mathrm{Cu}>\mathrm{Mn}>\mathrm{Cr}>\mathrm{Ni}>\mathrm{Cd}$ & Pourang and Amini (2001) \\
\hline Penaeusmerguiensis & Exoskeleton & $\mathrm{Fe}>\mathrm{Zn}>\mathrm{Cu}>\mathrm{Mn}>\mathrm{Cr}>\mathrm{Ni}>\mathrm{Cd}$ & Pourang and Amini (2001) \\
\hline Penaeusvannamei & Exoskeleton & $\mathrm{Fe}>\mathrm{Cu}>\mathrm{Zn}>\mathrm{Mn}>\mathrm{Ni}>\mathrm{Cd}$ & $\begin{array}{l}\text { Páez-Osuna and Tron-Mayen } \\
\text { (1996) }\end{array}$ \\
\hline Penaeusvannamei & Gills & $\mathrm{Fe}>\mathrm{Cu}>\mathrm{Zn}>\mathrm{Mn}>\mathrm{Ni}>\mathrm{Cd}$ & $\begin{array}{l}\text { Páez-Osuna and Tron-Mayen } \\
\text { (1996) }\end{array}$ \\
\hline $\begin{array}{l}\text { Penaeussemisulcatus } \\
((\text { De Haan, 1844) }\end{array}$ & Hepatopancreas & $\mathrm{Fe}>\mathrm{Zn}>\mathrm{Cu}>\mathrm{Cr}>\mathrm{Ni}>\mathrm{Pb}$ & Yilmaz and Yilmaz (2007) \\
\hline Penaeusvannamei & Hepatopancreas & $\mathrm{Fe}>\mathrm{Cu}>\mathrm{Zn}>\mathrm{Mn}>\mathrm{Ni}>\mathrm{Cd}$ & $\begin{array}{l}\text { Páez-Osuna and Tron-Mayen } \\
\text { (1996) }\end{array}$ \\
\hline Penaeusmonodon & Muscle & $\begin{array}{l}\mathrm{Zn}>\mathrm{Cu}>\mathrm{As}>\mathrm{Sr}>\mathrm{Se}>\mathrm{Mn}>\mathrm{Cr}> \\
\mathrm{Mo}>\mathrm{Pb}>\mathrm{Cd}\end{array}$ & Tu et al. (2008) \\
\hline Metapenaeusaffins & Muscle & $\mathrm{Zn}>\mathrm{Fe}>\mathrm{Cu}>\mathrm{Ni}>\mathrm{Cr}>\mathrm{Mn}>\mathrm{Cd}$ & Pourang and Amini (2001) \\
\hline Penaeussemisulcatus & Muscle & $\mathrm{Cu}>\mathrm{Fe}>\mathrm{Cr}>\mathrm{Zn}>\mathrm{Ni}>\mathrm{Pb}$ & Yilmaz and Yilmaz (2007) \\
\hline $\begin{array}{l}\text { Penaeuscaliforniensis } \\
\text { (Fabricius, 1798) }\end{array}$ & Muscle & $\mathrm{Zn}>\mathrm{Fe}>\mathrm{Cu}>\mathrm{Mn}$ & $\begin{array}{l}\text { Páez-Osuna and Tron-Mayen } \\
\text { (1996) }\end{array}$ \\
\hline $\begin{array}{l}\text { Penaeusindicus } \\
\text { (H. Milne-Edwards, 1837) }\end{array}$ & Muscle & $\mathrm{Zn}>\mathrm{Cu}>\mathrm{Cr}>\mathrm{Pb}>\mathrm{Ni}>\mathrm{Cd}$ & Joseph et al. (1992) \\
\hline $\begin{array}{l}\text { Penaeus kerathurus } \\
\text { (Forskål, 1775) }\end{array}$ & Muscle & $\begin{array}{l}\mathrm{Zn}>\mathrm{Cu}>\mathrm{Fe}>\mathrm{Ni}>\mathrm{Pb}>\mathrm{Mn}>\mathrm{Cr} \\
>\mathrm{Hg}>\mathrm{Cd}\end{array}$ & Balkas et al. (1982) \\
\hline Penaeus merguiensis & Muscle & $\mathrm{Zn}>\mathrm{Cu}>\mathrm{Mn}>\mathrm{Fe}>\mathrm{Hg}>\mathrm{Cd}, \mathrm{Ag}$ & Darmono and Denton (1990) \\
\hline Penaeusmerguiensis & Muscle & $\mathrm{Zn}>\mathrm{Cu}>\mathrm{Fe}>\mathrm{Cr}>\mathrm{Ni}>\mathrm{Mn}>\mathrm{Cd}$ & Pourang and Amini (2001) \\
\hline Penaeusmonodon & Muscle & $\mathrm{Zn}>\mathrm{Fe}>\mathrm{Pb}>\mathrm{Cd}$ & $\begin{array}{l}\text { Guhathakurta and Kaviraj } \\
(2000)\end{array}$ \\
\hline $\begin{array}{l}\text { Penaeusnotialis } \\
\text { (Pérez-Farfante, 1967) }\end{array}$ & Muscle & $\mathrm{Zn}>\mathrm{Fe}>\mathrm{Cu}>\mathrm{Hg}>\mathrm{Cd}$ & Biney and Ameyibor (1992) \\
\hline Penaeusvannamei & Muscle & $\mathrm{Zn}>\mathrm{Fe}>\mathrm{Cu}>\mathrm{Mn}>\mathrm{Cr}>\mathrm{Ni}>\mathrm{Cd}$ & $\begin{array}{l}\text { Páez-Osuna and Ruíz- } \\
\text { Fernández (1995b) }\end{array}$ \\
\hline Penaeusvannamei & Muscle & $\mathrm{Zn}>\mathrm{Fe}>\mathrm{Cu}>\mathrm{Mn}>\mathrm{Ni}>\mathrm{Cd}$ & $\begin{array}{l}\text { Páez-Osuna and Tron-Mayen } \\
\text { (1996) }\end{array}$ \\
\hline Penaeussemisulcatus & Allbody & $\mathrm{Zn}>\mathrm{Cu}>\mathrm{Co}>\mathrm{Pb}>\mathrm{Ni}>\mathrm{Cd}>\mathrm{Cr}$ & Sadiq et al. (2004) \\
\hline
\end{tabular}



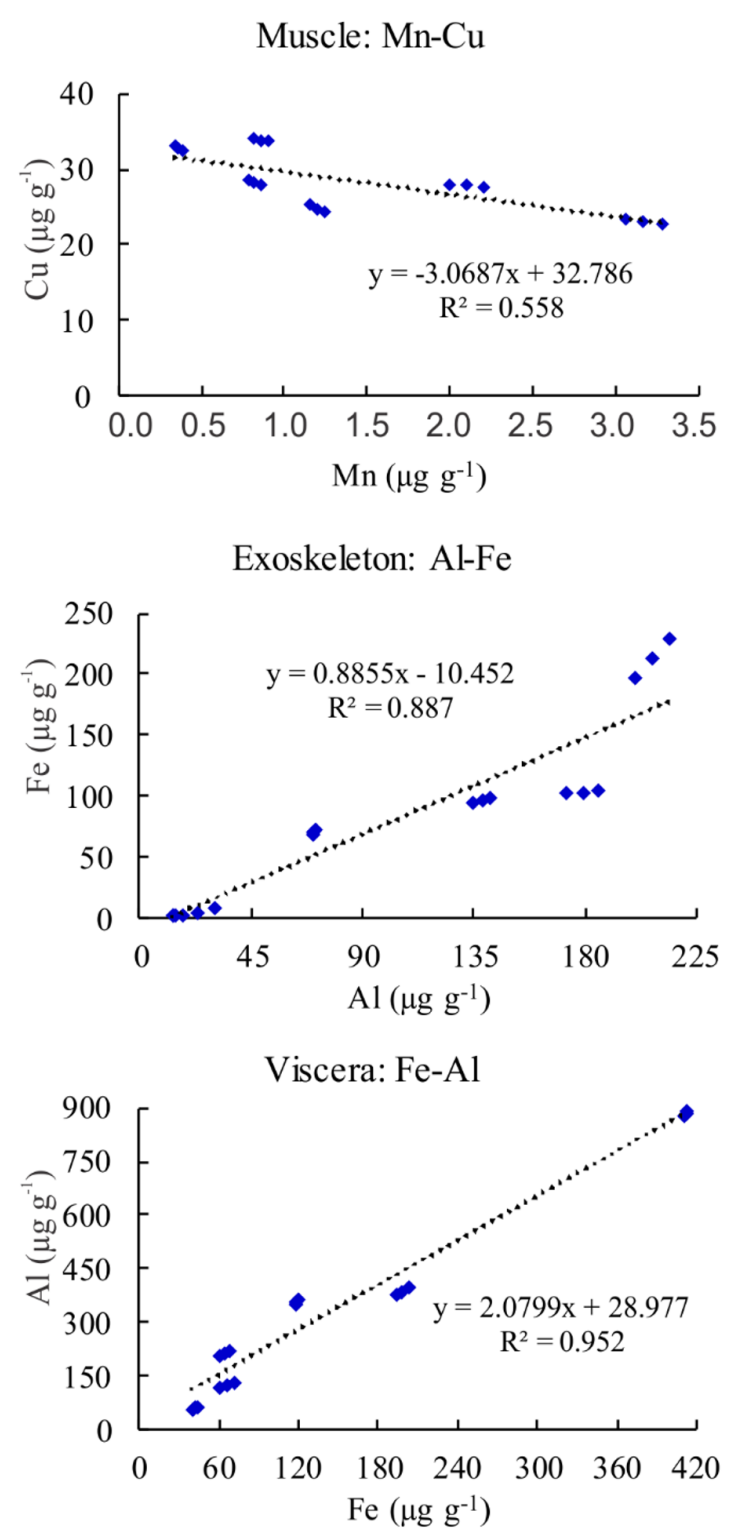
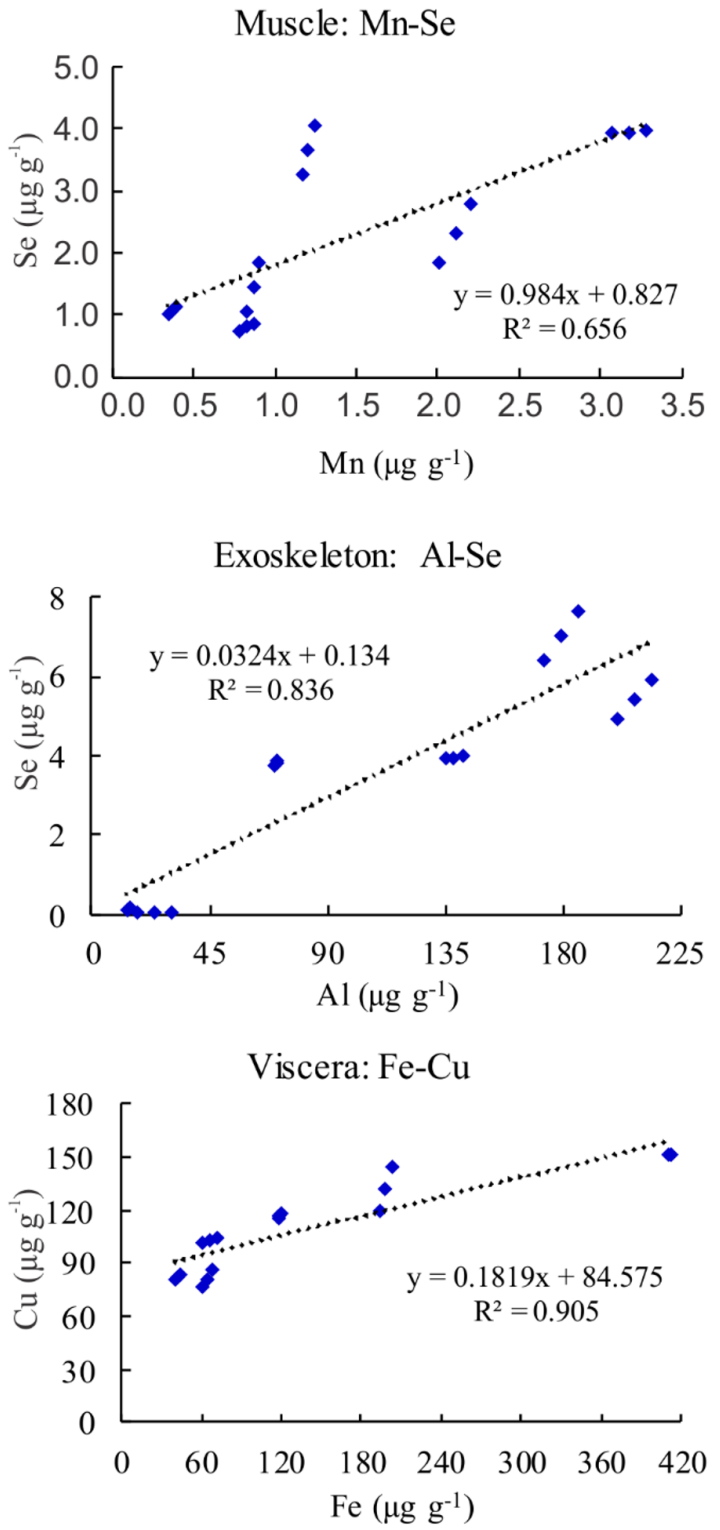

Figure 2. Linear regressions of pairs of elements exhibiting significant correlations $(\mathrm{p}<0.05)$.

elements with iron or selenium (Figure 2). For each tissue, were found the following significant correlations: muscle: $\mathrm{Fe}-\mathrm{Zn}(\mathrm{r}=-0.70), \mathrm{Mn}-\mathrm{Cu}(\mathrm{r}=-0.74), \mathrm{Se}-\mathrm{Cu}(\mathrm{r}=-0.68)$, Se-Mn ( $\mathrm{r}=0.82)$; exoskeleton: Fe-Al $(\mathrm{r}=0.94)$, Mn-Al $(\mathrm{r}=0.63), \mathrm{Mn}-\mathrm{Fe}(\mathrm{r}=0.62), \mathrm{Se}-\mathrm{Al}(\mathrm{r}=0.88), \mathrm{Se}-\mathrm{Fe}(\mathrm{r}=0.87)$, $\mathrm{Se}-\mathrm{Mn}(\mathrm{r}=0.58)$ and in the viscera: $\mathrm{Cu}-\mathrm{Zn}(\mathrm{r}=0.68), \mathrm{Al}-\mathrm{Cu}$ $(\mathrm{r}=0.88), \mathrm{Fe}-\mathrm{Cu}(\mathrm{r}=0.95)$ and $\mathrm{Fe}-\mathrm{Al}(\mathrm{r}=0.97)$.

Mason and Simkiss (1983) and Biney and Ameyibor (1992) suggest that a consistent association between metals may indicate a similarity in their biochemical mechanisms in the tissue. The relationship between the pairs of metals may be due to a competition or additional effect on the metal carriers and binders at the cellular level (Wright, 1995). This probably explains the high existing positive correlation being between the gills (presents in the viscera samples) and exoskeletons, which are related to tissue storage and detoxification of metals by shrimp, being the relationships likely influenced by such physiological mechanisms (Mendéz et al., 1999).

The hepatopancreas, included in this work in the examined the viscera, is a storage organ for metals excretion or transport them to other shrimp tissues. The exoskeleton is related to tissue to which metals are transported to detoxification such as $\mathrm{Fe}$ and $\mathrm{Al}$ from organisms through ecdysis (carapace change). Thus, the highest correlations of $\mathrm{Fe}$ and $\mathrm{Al}$ are observed in visceral tissues and exoskeletons. The Mn also showed relationship with these elements in the exoskeleton, probably because of its chemical similarity with calcium, the main structural component of the exoskeleton. 
Few studies report the relationship between trace elements in tissues of aquatic organisms and information about these relationships is still limited. However, studies suggest that a consistent association between metals may indicate a similarity in their biochemical mechanisms in the tissue.

Positive correlations $(\mathrm{p}<0.05)$ of $\mathrm{Cu}-\mathrm{Zn}$ were observed (Páez-Osuna and Ruíz-Fernández, 1995a) in muscles of P. merguiensis and M. affins. Significant positive correlations $(\mathrm{p}<0.01)$ in the exoskeleton of $M$. affins for pairs of metals: Fe-Mn $\left(\mathrm{R}^{2}=0.85\right)$ and Penaeus merguiensis with $\mathrm{Mn}-\mathrm{Fe}\left(\mathrm{R}^{2}=0.95\right)$ were also observed (Ruelas-Inzunza and Páez-Osuna, 2004). In muscles of several species form the Gulf of Fonseca (Central America) were also observed positive correlations $(\mathrm{p}<0.05)$ between $\mathrm{Cu}-\mathrm{Mn}$ and Fe-Mn (Carbonell et al., 1998).

\subsection{Risk health assessment}

$\mathrm{Cd}$ and $\mathrm{Pb}$ are categorized as toxic elements. $\mathrm{Al}, \mathrm{Cu}$, $\mathrm{Fe}, \mathrm{Mn}, \mathrm{Zn}, \mathrm{Mo}$ and Se are essentials elements. In Brazil, according to the Agência Nacional de Vigilância Sanitária (ANVISA, 1965), the permissible limits for $\mathrm{Cu}, \mathrm{Zn}, \mathrm{Se}, \mathrm{Cd}$ and $\mathrm{Pb}$ in fish for human consumption are 30.0, 50.0, 0.30, 1.0 and $2.0 \mu \mathrm{g} \mathrm{g}^{-1}$ of wet weight, respectively. The European Commission (EC) has considered lower limit of 0.05 and $0.3 \mu \mathrm{g} \mathrm{g}^{-1}$ of wet weight for $\mathrm{Cd}$ and $\mathrm{Pb}$, respectively (UE, 2008). According to Food and Agriculture Organisation (FAO, 1983), the limits for $\mathrm{Cd}$ and $\mathrm{Pb}$ in fish for human consumption are 0.5 and $0.05 \mu \mathrm{g} \mathrm{g}^{-1}$ of wet weight, respectively. In order to compare the data obtained in this study with prescribed limits, all concentrations were recalculated to wet weight.

Levels of Se in $67 \%$ of muscle and $50 \%$ of others tissues samples exceeded the ANVISA limit. Cd concentrations in $34 \%$ of other tissues samples (gills, stomach and liver) with detectable concentrations exceeded the EC limit. The concentrations of the other elements were under acceptable limits for human consumption according to all cited regulatory agency.

Research on other benthic species collected from the Todos os Santos Bay reported they found in oyster tissues, levels of toxic elements such as $\mathrm{Cd}, \mathrm{Cu}$ and $\mathrm{Ni}$ that may constitute a risk to the local human population who consume it (Amado-Filho et al., 2008).

\section{Conclusions}

The tissues analyzed from L. vannamei shrimp species showed different trends of bioaccumulation of the elements investigated. Aluminum and iron were the elements with the highest average concentrations among tissues. In all samples, the results of molybdenum and lead were below the limits of quantification. Cadmium contents were only observed in shrimp samples from coastal waters, suggesting a probable level of contamination.

The highest concentrations of the majority of elements have been found in the tissues of viscera, except for zinc and manganese.
The distribution of selenium concentration between tissues showed many variations between locations, and the concentration levels found in muscles of wild shrimp samples were high, indicating evidence of selenium bioaccumulation.

The different tissues showed a significant correlation between the following pairs of elements: $\mathrm{Fe}-\mathrm{Zn}, \mathrm{Mn}-\mathrm{Cu}$, $\mathrm{Se}-\mathrm{Cu}, \mathrm{Se}-\mathrm{Mn}$ in the muscles and Fe-Al, Mn-Al, Mn-Fe, $\mathrm{Se}-\mathrm{Al}, \mathrm{Se}-\mathrm{Fe}, \mathrm{Se}-\mathrm{Mn}$ in the exoskeleton and $\mathrm{Cu}-\mathrm{Zn}, \mathrm{Al}-\mathrm{Cu}$, $\mathrm{Fe}-\mathrm{Cu}, \mathrm{Fe}-\mathrm{Al}$ in the viscera.

Levels of Se of some tissues of shrimp were found to exceed their permissible levels in food. However, the levels of $\mathrm{Cd}$ and $\mathrm{Pb}$ in shrimp muscles of this study were within the permissible limits in fish muscle for human consumption to the Brazilian standard, European Commission (EC) and the Food and Agriculture Organization (FAO).

\section{Acknowledgements}

The authors are grateful for the financial support received from Fundação de Amparo a Pesquisa do Estado da Bahia (FAPESB) and Coordenação de Aperfeiçoamento de Pessoal de Nível Superior (CAPES).

\section{References}

AGÊNCIA DE VIGILÂNCIA SANITÁRIA - ANVISA, 1965 [viewed 15 August 2014]. Decreto $n^{\circ} 55871$, de 26 de março de 1965. Modifica o Decreto $n^{\circ} 50.040$, de 24 de janeiro de 1961, referente a normas reguladoras do emprego de aditivos para alimentos, alterado pelo Decreto $n^{\circ} 691$, de 13 de março de 1962. Diário Oficial da União [online], Brasília, 9 abr. 1965. Available from: http://www.anvisa.gov.br/legis/decretos/55871_65.htm

ALLIOT, A. and FRENET-PIRON, M., 1990. Relationship between metals in seawater and metal accumulation in shrimps. Marine Pollution Bulletin, vol. 21, no. 1, pp. 30-33. http://dx.doi. org/10.1016/0025-326X(90)90149-3.

AMADO-FILHO, G.M., SALGADO, L.T., REBELO, M.F., REZENDE, C.E., KAREZ, C.S. and PFEIFFER, W.C., 2008. Heavy metals in benthic organisms from Todos os Santos Bay, Brazil. Brazilian Journal of Biology = Revista Brasileira de Biologia, vol. 68, no. 1, pp. 95-100. http://dx.doi.org/10.1590/ S1519-69842008000100013. PMid:18470382.

AMARAL, M.C.R., REBELO, A.M.F., TORRES, J.P.M. and PFEIFFER, W.C., 2005. Bioaccumulation and depuration of Zn and Cd in mangrove oysters Crassostrea rhizophorae, Guilding, 1828) transplanted to and from a contaminated tropical coastal lagoon. Marine Environmental Research, vol. 59, no. 4, pp. 277-285. http://dx.doi.org/10.1016/j.marenvres.2004.05.004. PMid:15589982.

BALKAS, T.I., TURUL, S. and SALIHOLU, I., 1982. Trace metal levels in fish and crustaceans from northeastern Mediterranean coastal waters. Marine Environmental Research, vol. 6, no. 4, pp. 281-289. http://dx.doi.org/10.1016/0141-1136(82)90042-3.

BAMBANG, Y., THUET, P., CHARMANTIER-DAURES, M., TRILLES, J.P. and CHARMANTIER, G., 1995. Effect of copper on survival and osmoregulation of various developmental stage of the shrimp Penaeus japonicus bate (Crustacea, Decapoda). 
Aquatic Toxicology, vol. 33, no. 2, pp. 125-139. http://dx.doi. org/10.1016/0166-445X(95)00011-R.

BINEY, C.A. and AMEYIBOR, E., 1992. Trace metal concentrations in the pink shrimp Penaeus notialis from the coast of Ghana. Water, Air, and Soil Pollution, vol. 63, no. 3-4, pp. 273-279. http:// dx.doi.org/10.1007/BF00475494.

BRYAN, G.W. and LANGSTON, W.I., 1992. Bioavailability, accumulation and effects of heavy metals in sediments with special reference to United Kingdom estuaries: a review. Environmental Pollution, vol. 76, no. 2, pp. 89-131. http://dx.doi.org/10.1016/02697491(92)90099-V. PMid:15091993.

CARBONELL, G., RAMOS, C. and TARAZONA, J.V., 1998. Metals in shrimp culture areas from the Gulf of Fonseca, Central America. I. Sediments. Archives of Environmental Contamination and Toxicology, vol. 60, no. 2, pp. 252-259. http://dx.doi. org/10.1007/s001289900618. PMid:9470986.

DARMONO, D. and DENTON, G.R.W., 1990. Heavy metal concentrations in the banana prawn, Penaeus merguiensis, and leader prawn, P. monodon, in the Townsville region of Australia. Bulletin of Environmental Contamination and Toxicology, vol. 44, no. 3, pp. 479-486. http://dx.doi.org/10.1007/BF01701233. PMid:2328357.

DEPLEDGE, M.H., FORBES, T.L. and FORBES, V.E., 1993. Evaluation of cadmium, copper, zinc and iron concentrations and tissue distributions in the benthic crab, Dorippe granulata (De Haan, 1841) from Tolo Harbour, Hong Kong. Environmental Pollution, vol. 81, no. 1, pp. 15-19. http://dx.doi.org/10.1016/02697491(93)90023-H. PMid:15091832.

DIODATO, S., COMOGLIO, L., CAMILIÓN, C. and AMIN, O., 2012. Responses of the resident rocky crab (Halicarcinus planatus, Decapoda) to natural stressors and effluent discharges in Ushuaia Bay, Tierra del Fuego, Argentina. Journal of Experimental Marine Biology and Ecology, vol. 436-437, pp. 11-18. http:// dx.doi.org/10.1016/j.jembe.2012.08.011.

DURAL, M., GÖKSU, M.Z.L. and ÖZAK, A.A., 2007. Investigation of heavy metal levels in economically important fish species captured from the Tuzla Lagoon. Food Chemistry, vol. 102, no. 1, pp. 415-421. http://dx.doi.org/10.1016/j.foodchem.2006.03.001.

DURAN, C., GUNDOGDU, A., BULUT, V.N., SOYLAK, M., ELCI, L., SENTÜRK, H.B. and TÜFEKCI, M., 2007. Solid-phase extraction of $\mathrm{Mn}(\mathrm{II}), \mathrm{Co}(\mathrm{II}), \mathrm{Ni}(\mathrm{II}), \mathrm{Cu}(\mathrm{II}), \mathrm{Cd}(\mathrm{II})$ and $\mathrm{Pb}(\mathrm{II})$ ions from environmental samples by flame atomic absorption spectrometry (FAAS). Journal of Hazardous Materials, vol. 146, no. 1-2, pp. 347-355. http://dx.doi.org/10.1016/j.jhazmat.2006.12.029. PMid:17223260.

FALLAH, A.A., SAEI-DEHKORDI, S.S., NEMATOLLAHI, A. and JAFARI, T., 2011. Comparative study of heavy metal and trace element accumulation in edible tissues of farmed and wild rainbow trout (Oncorhynchus mykiss) using ICP-OES technique. Microchemical Journal, vol. 98, no. 2, pp. 275-279. http://dx.doi. org/10.1016/j.microc.2011.02.007.

FERREIRA, A.G., MACHADO, A.L.S. and ZALMON, I.R., 2005. Temporal and spatial variation on heavy metal concentrations in the oyster Ostrea equestris on the northern coast of Rio de Janeiro state, Brazil. Brazilian Journal of Biology $=$ Revista Brasileira de Biologia, vol. 65, no. 1, pp. 67-76. http://dx.doi.org/10.1590/ S1519-69842005000100010. PMid:16025905.
FIRAT, O., GÖK, G., COĞUN, H.Y., YÜZEREROĞLU, T.A. and KARGIN, F., 2008. Concentrations of $\mathrm{Cr}, \mathrm{Cd}, \mathrm{Cu}, \mathrm{Zn}$ and $\mathrm{Fe}$ in crab Charybdis longicollis and shrimp Penaeus semisulcatus from the Iskenderun Bay, Turkey. Environmental Monitoring and Assessment, vol. 147, no. 1-3, pp. 117-123. http://dx.doi. org/10.1007/s10661-007-0103-7. PMid:18095182.

FOOD AND AGRICULTURE ORGANIZATION - FAO, 1983 [viewed 15 December 2015]. Compilation of legal limits for hazardous substances in fish and fishery products [online]. Rome, pp. 5-100. Fishery Circular, no. 464. Available from: http://www. fao.org/docrep/014/q5114e/q5114e.pdf

FU, Z., WU, F., MO, C., LIU, B., ZHU, J., DENG, Q., LIAO, H. and ZHANG, Y., 2011. Bioaccumulation of antimony, arsenic, and mercury in the vicinities of a large antimony mine, China. Microchemical Journal, vol. 97, no. 1, pp. 12-19. http://dx.doi. org/10.1016/j.microc.2010.06.004.

GRÄSLUND, S. and BENGTSON, B., 2001. Chemical and biological products used in south-est Asian shrimp farming, and their potential impact on the environment: a review. The Science of the Total Environment, vol. 280, no. 1-3, pp. 93-131. http:// dx.doi.org/10.1016/S0048-9697(01)00818-X. PMid:11763276.

GUHATHAKURTA, H. and KAVIRAJ, A., 2000. Heavy metal concentration in water, sediment, shrimp (Penaeus monodon) and mullet (Liza parsia) in some brackish water ponds of Sunderban, India. Marine Pollution Bulletin, vol. 40, no. 11, pp. 914-920. http://dx.doi.org/10.1016/S0025-326X(00)00028-X.

HARDING, L.E., GRAHAM, M. and PATON, D., 2005. Accumulation of selenium and lack of severe effects on productivity of american dippers (Cinclus mexicanus) and spotted sandpipers (Actitis macularia). Environmental Monitoring and Assessment, vol. 48, no. 3, pp. 414-423. PMid:15750773.

JOSEPH, K.O., SRIVASTAVA, J.P. and KADIR, P.M.A., 1992. Acute toxicity of five heavy metals to the prawn, Penaeus indicus (H. Milne Edwards) in brackish waters medium. Journal of the Inland Fisheries Society of India, vol. 24, pp. 82-84.

KARGIN, F., DONMÊZ, A. and ÇOGUN, H.Y., 2001. Distribuition of heavy metals in diferent tissues of the shrimp Penaeus semiculatus and Metapenaeus monocerus from the Iskenderun Gulf, Turkey. Archives of Environmental Contamination and Toxicology, vol. 66, pp. 102-109. http://dx.doi.org/10.1007/s001280000211.

LACERDA, L.D., SANTOS, J.A. and LOPES, D.V., 2009. Fate of copper in intensive shrimp farms: bioaccumulation and deposition in pond sediments. Brazilian Journal of Biology $=$ Revista Brasileira de Biologia, vol. 69, no. 3, pp. 851-858. http:// dx.doi.org/10.1590/S1519-69842009000400012. PMid:19802444.

LEMLY, A.D., 1995. A Protocol for aquatic hazard assessment of selenium. Ecotoxicology and Environmental Safety, vol. 32, no. 3, pp. 280-288. http://dx.doi.org/10.1006/eesa.1995.1115. PMid:8964256.

MANSOUR, S.A. and SIDKY, M.M., 2002. Ecotoxicological Studies. 3. Heavy metals contaminating water and fish from Fayoum Governorate, Egypt. Food Chemistry, vol. 78, no. 1, pp. 15-22. http://dx.doi.org/10.1016/S0308-8146(01)00197-2.

MARTIN, J.L.M., 1974. Metals in cancer irroratus (Crustacea: Decapoda): concentration factors, discrimination factors, correlations. Journal of Marine Biology, vol. 28, no. 4, pp. 245-251. http:// dx.doi.org/10.1007/BF00388491. 
MASON, A.Z. and SIMKISS, K., 1983. Interactions between metals and their distribution in tissues of Littorina littorea (L.) collected from clean and polluted sites. Journal of Marine Biology, vol. 63, no. 3, pp. 661-672. http://dx.doi.org/10.1017/ S0025315400070971.

MAY, T.W., WALTHER, M.J., PETTY, J.D., FAIRCHILD, J.F., LUCERO, J., DELVAUX, M., MANRING, J., ARMBRUSTER, M. and HARTMAN, D., 2001. An evaluation of selenium concentrations in water, sediment, invertebrates, and fish from the republican river basin: 1997-1999. Environmental Monitoring and Assessment, vol. 72, no. 2, pp. 179-206. http://dx.doi. org/10.1023/A:1012041003657. PMid:11720223.

MENDÉZ, L., ACOSTA, A. and RACOTTA, I., 1999. Mineral concentrations in muscle and hepatopancreas of newly caught wild and hatchery-exhausted spawners of pacific white shrimp, Penaeus vannamei. Journal of Applied Aquaculture, vol. 4, pp. 17-26.

MINGOTI, A.S., 2007. Análise de dados através de métodos de estatística multivariada: uma abordagem aplicada. 1st ed. Belo Horizonte: Universidade Federal de Minas Gerais. 510 p.

PÁEZ-OSUNA, F. and RUÍZ-FERNÁNDEZ, C., 1995a. Comparative bioacumulation of trace metals in Penaues stylirostris in estuarine and coastal environments. Estuarine, Coastal and Shelf Science, vol. 40, no. 1, pp. 35-44. http://dx.doi.org/10.1016/02727714(95)90011-X.

PÁEZ-OSUNA, F. and RUÍZ-FERNÁNDEZ, C., 1995b. Trace metals in the mexican shrimp Penaeus vannamei from estuarine and marine environments. Archives of Environmental Contamination and Toxicology, vol. 87, no. 2, pp. 243-247. PMid:15091599.

PÁEZ-OSUNA, F. and TRON-MAYEN, L., 1996. Concentration and distribution of heave metals in tissue of wild and farmed shrimp Penaeus vannamei from the north-west coast of Mexico. Archives of Environmental Contamination and Toxicology, vol. 22, pp. 443-450.

PETERSON, M.J., SMITH, J.G., SOUTHWORTH, G.R., RYON, M.G. and EDDLEMON, G.K., 2002. Trace element contamination in benthic macroinvertebrates from small stream near a uranium mill tailings site. Environmental Monitoring and Assessment, vol. 74, no. 2, pp. 193-208. http://dx.doi.org/10.1023/A:1013872103460. PMid:11878642.

PODRUG, M. and RASPOR, B., 2009. Seasonal variation of the metal $(\mathrm{Zn}, \mathrm{Fe}, \mathrm{Mn})$ and metallothionein concentrations in the liver cytosol of the European chub (Squalius cephalus L.). Environmental Monitoring and Assessment, vol. 157, no. 1-4, pp. 1-10. http:// dx.doi.org/10.1007/s10661-008-0509-x. PMid:18758978.

POURANG, N. and AMINI, G., 2001. Distribution of trace elements in tissues of two shrimp species from Persian Gulf and effects of storage temperature on elements transportations. Water, Air, and Soil Pollution, vol. 129, no. 1-4, pp. 229-243. http:// dx.doi.org/10.1023/A:1010371713798.

POURANG, N., DENNIS, J.H. and GHOURCHIAN, H., 2004. Tissue distribution and redistribution of trace elements in shrimp species with the emphasis on the roles of metallothionein. Ecotoxicology, vol. 13, no. 6, pp. 519-533. http://dx.doi. org/10.1023/B:ECTX.0000037189.80775.9c. PMid:15526858.

RUELAS-INZUNZA, J. and PÁEZ-OSUNA, F., 2004. Distribution and concentration of trace metals in tissues of three penaeid shrimp species form Altata-Ensenada del Pabellón Lagoon (SE Gulf of California). Archives of Environmental Contamination and Toxicology, vol. 72, no. 3, pp. 452-459. http://dx.doi.org/10.1007/ s00128-004-0267-6. PMid:15114442.

SADIQ, M., ZAIDI, T.H., HODA, A. and MIAN, A.A., 2004. Heavy metal of health significance in commonly consumed shrimps in the eastern province of Saudi Arabia. Journal of Environmental Science and Health, vol. 29, pp. 313-319.

SANTOS, É.J., SANTOS, A.B., HERRMANN, A.B., KULIK, S., BAIKA, L.M., TORMEN, L. and CURTIUS, A.J., 2013. Simultaneous determination of $\mathrm{Pb}$ and $\mathrm{Cd}$ in seafood by ICP OES with on-line pre-concentration by solid phase extraction with amberlite XAD-4 after complex formation with DDTP. Brazilian Archives of Biology and Technology, vol. 56, no. 1, pp. 127-134. http://dx.doi.org/10.1590/S1516-89132013000100017.

SEEBAUGH, D.R., GOTO, D. and WALLACE, W.G., 2005. Bioenhancement of cadmium transfer along a multi-level food chain. Marine Environmental Research, vol. 59, no. 5, pp. 473-491. http://dx.doi.org/10.1016/j.marenvres.2004.07.003. PMid:15603770.

SOEGIANTO, A., CHARMANTIER-DAURES, M., TRILLES, J.P. and CHARMANTIER, G., 1999. Impact of cadmium on the structure of gills and epipodites of the shrimp Penaeus japonicas. Aquatic Living Resources, vol. 12, no. 1, pp. 57-60. http://dx.doi. org/10.1016/S0990-7440(99)80015-1.

SONI, M.G., WHITE, S.M., FLAMM, W.G. and BURDOCK, G.A., 2001. Safety evaluation of dietary aluminum. Regulatory Toxicology and Pharmacology, vol. 33, no. 1, pp. 66-79. http:// dx.doi.org/10.1006/rtph.2000.1441. PMid:11259180.

TU, N.P.C., HA, N.N., IKEMOTO, T., TUYEN, B.C., TANABE, S. and TAKEUCHI, I., 2008. Regional variations in trace element concentrations in tissues of black tiger shrimp Penaeus monodon (Decapoda: Penaeidae) from South Vietnam. Marine Pollution Bulletin, vol. 57, no. 6-12, pp. 858-866. http://dx.doi.org/10.1016/j. marpolbul.2008.02.016. PMid:18395229.

TUZEN, M. and SOYLAK, M., 2007. Determination of trace metals in canned fish marketed in Turkey. Food Chemistry, vol. 101, no. 4, pp. 1378-1382. http://dx.doi.org/10.1016/j. foodchem.2006.03.044.

UNIÓN EUROPEA - UE. Commission Regulation - EC, 2008 [viewed 15 December 2015]. Regulamento (CE) $n^{\circ}$ 629/2008 da Comissão, de 2 de julho de 2008, que altera o Regulamento (CE) $n^{\circ}$ 1881/2006 que fixa os teores máximos de certos contaminantes presentes nos géneros alimentícios. Jornal Oficial da União Europeia [online], Bruxelas, 2 jul. pp. 6-9. vol. 51. Available from: http://eur-lex.europa.eu/legal-content/PT/TXT/PDF/?uri $=$ CELEX:32008R0629\&from $=\mathrm{EN}$

VANEGAS, C., ESPINA, S., BOTELLO, A.V. and VILLANUEVA, S., 1997. Acute toxicity and synergism of cadmium and zinc in white shrimp, Penaeus setiferus, Juveniles. Archives of Environmental Contamination and Toxicology, vol. 58, no. 1, pp. 87-92. http:// dx.doi.org/10.1007/s001289900304. PMid:8952930.

WHITE, R.R., HARDAWAY, C.J., RICHERT, J.C. and SNEDDON, J., 2012. Selenium-lead interactions in crawfish (Procambrus clarkii) in a controlled laboratory environment. Microchemical Journal, vol. 102, pp. 91-114. http://dx.doi.org/10.1016/j. microc.2011.12.005. 
WRIGHT, D.A., 1995. Trace metal and major ion interactions in aquatic animals. Marine Pollution Bulletin, vol. 31, no. 1-3, pp. 8-18. http://dx.doi.org/10.1016/0025-326X(95)00036-M.

WU, J.P. and CHEN, H.C., 2004. Effects of cadmium and zinc on oxigen consumption, ammonium excretion, and osmorregulation of whit shrimp (Litopenaeus vannamei). Chemosphere, vol. 57, no. 11, pp. 1591-1598. http://dx.doi.org/10.1016/j.chemosphere.2004.07.033. PMid:15519404.

YETIMOGLU, E.K., KAHRAMAN, M.V., ERCAN, Ö., AKDEMIR, Z.S. and KAYAMAN, N., 2007. N-vinylpyrrolidone/acrylic acid/2-acrylamido-2-methylpropane sulfonic acid based hydrogels: synthesis, characterization and their application in the removal of heavy metals. Reactive \& Functional Polymers, vol. 67, no. 5, pp. 451-460. http://dx.doi.org/10.1016/j.reactfunctpolym.2007.02.007.

YILMAZ, A.B. and YILMAZ, L., 2007. Influences of sex and seasons on levels of heavy metals in tissues of green tiger shrimp (Penaeus semisulcatus de Hann, 1844). Food Chemistry, vol. 101, no. 4, pp. 1664-1669. http://dx.doi.org/10.1016/j. foodchem.2006.04.025.

YILMAZ, A.B., 2003. Levels of heavy metals (Fe, Cu, Ni, Cr, Pb, and $\mathrm{Zn}$ ) in tissue of Mugil cephalus and Trachurus mediterraneus from Iskenderun Bay, Turkey. Environmental Research, vol. 92, no. 3, pp. 277-281. http://dx.doi.org/10.1016/S0013-9351(02)000828. PMid: 12804525. 